\title{
Evaluation of the Extract Obtained from Various Medicinal and Aromatic Plants "Antibacterial and antioxidant" in the Wood Industry
}

\author{
Huseyin Peker ${ }^{(1)}{ }^{*}$, Hatice Ulusoy ${ }^{(\mathbb{D} 2}$
}

${ }^{1}$ Department of Forest Industrial Engineering, Forest Faculty, Artvin Çoruh University, Artvin, Turkey
${ }^{2}$ Department of Forest, Köyceğiz Vocational School, Muğla Sitkı Koçman University, Muğla, Turkey

Abstract: Throughout the history of mankind, various plants (medicinal aromatics etc.) have been used naturally to prevent all diseases, or they have been used in a wide range of fields, especially in the pharmaceutical industry, by cultivating in agriculture/greenhouse areas. However, as a result of the protection and coloring of the wood material by chemically, especially the indoor contamination causes negative effects on human health. The main objective of this study is to use the wooden product in wooden child toys, hospitals, sterile areas, pharmacies, wood-based materials used in the kitchen (fork, knife, serving plates and chopping boards etc.), playgrounds, dining table surfaces, nursery and kindergarten furniture, beehives etc. In addition, it will be recommended to use on all surfaces where there is an antibacterial / antioxidant effect, as well as on the surfaces with collective contact such as door handles, cabinet handles, elevator buttons and cash dispenser keys. In research, extracts of Evelik (Rumex patientia L.) and Çakşır (Ferula comunis L.) herbs ( $1 \%$ concentration) from medicinal aromatic plants were prepared and spruce and mahogany wood were used as wood type. According to ASTM D 143-76 principles, retention and bending resistance properties were determined by impregnation according to the results of the experiment, the highest retention $(0.55 \%)$ and bending strength $\left(100.20 \mathrm{~N} / \mathrm{mm}^{2}\right)$ were determined in Evelik plant and the optimum increase was determined when the results were compared with the control sample.

\section{ARTICLE HISTORY}

Received: Mar. 03, 2021

Revised: Apr. 11, 2021

Accepted: May 01, 2021

\section{KEYWORDS}

Human/Environmental, Medicinal Aromatic Plants, Wood,

Toys.

\section{INTRODUCTION}

With It is estimated that there are approximately 1000000 plants in the world today. Nearly 500000 of these species have been identified and named, and as a result of the researches conducted by the World Health Organization (WHO), it has been determined that they consist of medicinal plants used for treatment. The amount of medicinal plants used for treatment in our country is at least 500 (Baytop, 1984). From existence of mankind until recently, human beings provided almost all their needs such as clothing, shelter, food and fuel from within the boundaries of forests. But today, the development of technology, forestry method and forest management has focused the needs of people obtained from forests only on wood raw materials. 
In our country, this understanding has started to prevail day by day and started to be limited to wood (log, lumber, etc.) production. However, it is an incomparable resource for a healthy life, in which many economic and cultural activities such as many herbaceous plants, wild animals, water resources, recreation areas can be carried out together, except for the tree wealth within forest areas (Özkan \& Akbulut, 2014). It is a very old tradition that medicinal plants started to be used in cure of diseases with the settlement of mankind. In many developing countries, herbal medicines constitute an important part of the culture and traditions in rural communities. Plants have a wide variety of chemical substances that have important biological activities on humans (Njume et al., 2010).

In addition to compounds with antioxidant activity in plants, it is known that there are biological activities in essential oils and herbal extracts obtained from various plants. In scientific researches, it has been proven that the antimicrobial substances found in herbal extracts are able to preserve the food safety at a high rate and because of these properties, plants can be used as natural antimicrobials (Souza et al., 2005). Many herbs known as medicinal plants have been found by the public through trial and error. The use of such wild plants in the treatment of diseases in the world and in our country lies back to ancient times (Yiğit \& Benli, 2005). It has been reported that wood is subjected to impregnation with some vegetable oil structure and as a result, there are increases in weight and density values (Bazyar et al., 2010). Since the use of toxic component structure in wood preservation has caused the increase of important environmental pressures and prohibitions, it has been necessary to create/develop new environmentally friendly materials (Tomak, 2011).

Rapid reduction in forest existence and exposure of human beings to synthetic/chemical effects in the environment they live, cause serious threats. Natural plants are used for various purposes (medical, cosmetic, food, spice, agriculture, animal husbandry, spice, paint industry, etc.); The antioxidant/anti-bacterial properties of the organic wood were determined by obtaining various concentrations (1\%) of plant extracts and the impregnation feature and some technological properties, as well as a hygienic structure in wood.

\section{MATERIAL and METHODS}

\subsection{Wood Material and Plant Type}

Spruce grown in our country and Mahogany wood which is an imported wood type were used in the study. Processes were carried out by cutting in radial direction according to the principles of TS 2470 (TSE, 1976 ). Çakşır (Ferula comunis L.) and Evelik (Rumex patientia L.) plants , whose antibacterial/antioxidant properties have been determined in the literature, were chosen (Çetin, 2017).

\subsection{Experiment Sample Preparation}

While the samples were being prepared, the smoothness of the fibrous structure of the wood was considered and it was prepared for the sapwood (TS 2471) without any cracks, knots and color defects. Air-dried samples were prepared according to the principles of TS EN 2474 for flexure resistance $\left(\mathrm{TSE}, 1976^{\mathrm{b}}, \mathrm{TSE}, 1976^{\mathrm{c}}\right)$.

\subsection{Impregnation Process}

The impregnation process was applied in accordance with the conditions in "ASTM-D 141376" (1984). Experimental samples were prepared in the dimensions of 20x20x300 $\pm 1 \mathrm{~mm}$ and subjected to 45 minutes vacuum/45 minutes diffusion process. In order to prevent impregnated.

\subsection{Obtaining Plant Extract}

The sample weight determined for the experiment is put in $200 \mathrm{~mL}$ of hot distilled water or water at least equal to this purity and heated at a temperature below the boiling point in the 
refluxing apparatus for 1 hour by mixing at certain intervals, after filtering in the previously prepared porous capsule with vacuum, no sample will remain in the balloon. The process was continued to be washed several times with distilled water and the insoluble part was completely left inside the porous capsule. Finally, the residue was washed with $200 \mathrm{~mL}$ of hot distilled water and after the residue was dehydrated by a pump or another device that would serve as a suction, the porous capsule and its contents were dried by keeping it in an oven set at $103^{\circ} \mathrm{C}$ for 16 hours, then cooled in a desiccator and weighed with $0.001 \mathrm{~g}$ precision (Ceylan, 1997).

\subsection{Retention Amount (\% Rate)}

$1.0 \mathrm{~g}$ After the impregnation process, the remaining substance (tcoao- $\%$ retention) compared to the complete dry wood was calculated (1) from the formula (Baysal, 1994).

$$
\mathrm{R}(\%)=((\text { Wfdia-Wfdib }) / \mathrm{Wfdib}) \times 100
$$

Wfdia $=$ Sample full dry weight after impregnation $(\mathrm{g})$

$\mathrm{Wfdib}=$ sample full dry weight before impregnation $(\mathrm{g})$

\subsection{Bending Strength}

Bending Strength is based on TS 2474/1976 standard. The samples were prepared in 20x20x360 $\mathrm{mm}$ dimensions. The samples were sanded and air-conditioned $\left(20 \pm 2{ }^{\circ} \mathrm{C} / 65 \pm 5 \%\right.$ relative humidity) to $12 \%$ humidity. Before the experiments, all samples were air dried and values were taken by measuring both thicknesses (radial/tangent) with a digital caliper with $\pm 0.01 \mathrm{~mm}$ precision. Then, the speed of the loading mechanism of the universal testing machine was adjusted to break in $1.5 \pm 0.5$ minutes. The flexural resistance was calculated (2) with the help of the equation given below (Çıtak, 2012).

$$
\text { Bending strength }\left(\mathrm{N} / \mathrm{mm}^{2}\right): \delta_{\theta}=\left(3 \times \mathrm{P}_{\max } \times \mathrm{L}_{\mathrm{s}}\right) /\left(2 \times \mathrm{b} \times \mathrm{h}^{2}\right)
$$

Pmax: Force at break (N), Ls: Clearance between abutments (mm), b: Sample width (mm), $\mathrm{h}$ : Sample thickness $(\mathrm{mm})$.

\section{RESULTS and DISCUSSION}

\subsection{Solution Properties}

Solution properties are given in Table 1.

\begin{tabular}{|c|c|c|c|c|c|c|c|}
\hline \multirow{2}{*}{ Concentration } & \multirow{2}{*}{ Extract } & \multirow{2}{*}{ Solvent } & \multirow{2}{*}{$\begin{array}{c}\text { Temperature } \\
\left({ }^{\circ} \mathrm{C}\right)\end{array}$} & \multicolumn{2}{|c|}{$\mathrm{pH}$} & \multicolumn{2}{|c|}{ Density $(\mathrm{g} / \mathrm{mL})$} \\
\hline & & & & $\mathrm{BI}$ & $\mathrm{AI}$ & $\mathrm{BI}$ & $\mathrm{AI}$ \\
\hline \multirow{2}{*}{$\% 1$} & $\begin{array}{l}\text { Rumex } \\
\text { patientia L. }\end{array}$ & \multirow{2}{*}{$\begin{array}{l}\text { Distilled } \\
\text { Water }\end{array}$} & \multirow{2}{*}{$22^{\circ} \mathrm{C}$} & 6.07 & 6.07 & 0.987 & 0.987 \\
\hline & $\begin{array}{l}\text { Ferula } \\
\text { comunis L. }\end{array}$ & & & 7.17 & 7.17 & 0.987 & 0.987 \\
\hline
\end{tabular}

Table 1. Solution Properties of Ferula comunis L. and Rumex patientia L.

AI: After impregnation, BI: Before impregnation

When the table is examined, no significant changes were determined before and after impregnation. It is known that the $\mathrm{pH}$ factor being close to acidic character creates a negative structure on the mechanical properties. 


\subsection{Retention Amount (\% Retention)}

The net dry impregnation material (retention) remaining amount as (\%) is given in Table 2 and Figure 1.

Table 2. \% Retention of Çakşır (Ferula comunis L.) and Evelik (Rumex patientia L.)

\begin{tabular}{|c|c|c|c|c|}
\hline Wood Type & Concentration & Extract & $\begin{array}{c}\text { Vacuum/Diffusion } \\
\text { Time (Min) } \\
\end{array}$ & Retention (\%) \\
\hline Snruce Whod & $0<1$ & Rumex patientia L. & \multirow{4}{*}{$45 \mathrm{~min}$} & 0.55 \\
\hline \multirow{3}{*}{$\begin{array}{l}\text { Mahogany } \\
\text { Wood }\end{array}$} & \multirow{3}{*}{$\% 1$} & Ferula comunis L. & & 0.35 \\
\hline & & Rumex patientia L. & & 0.16 \\
\hline & & Ferula comunis L. & & 0.60 \\
\hline
\end{tabular}

Figure 1. Change in adhesion amount in impregnated and control groups (\%).

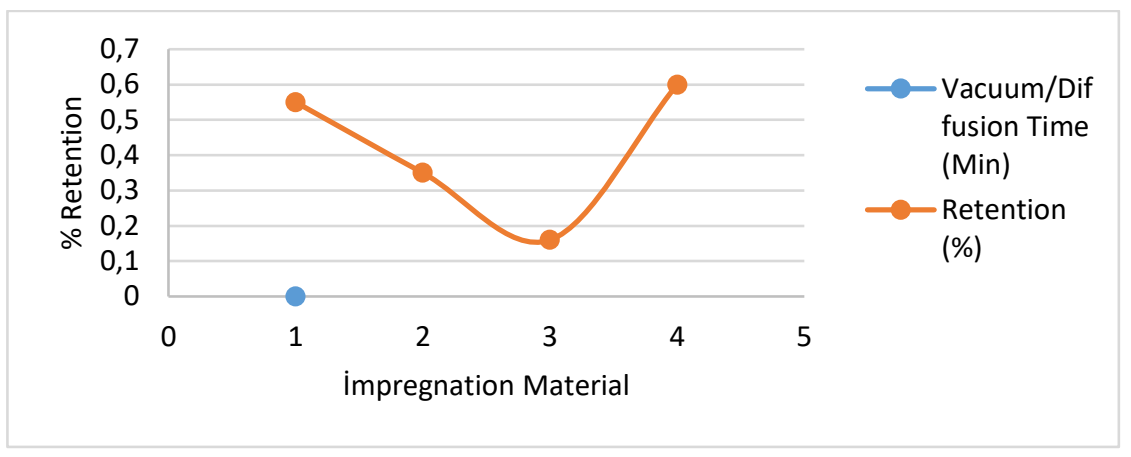

The highest adhesion was detected in mahogany wood in Çakşır plant (Ferula comunis L.) $(0.60 \%)$ and the lowest in mahogany wood in Evelik plant (Rumex patientia L.) $(0.16 \%)$. The level of adhesion can vary according to the wood type, anatomical structure, impregnation method and impregnation material; This feature (adhesion) can reveal different interactions in technological properties. The retention amount varies according to the wood type and other factors (thickness, wood type, anatomy, moisture, impregnation method, impregnation material). Similar results are observed when the results are compared with the literature. Bal (2006) reported that the process performed with ACQ in wood is effective on the mechanical properties and retention is positively affected and provides rapid penetration. Alkan (2016) impregnated the scotch pine wood with boron compounds and kebracodan, and reported that the highest retention occurred at 1\% concentration. Özçifçi et al. (2009) reported in their study that the highest $\%$ retention value was found in the samples treated with pressure-vacuum method in scotch pine, the highest \% retention value was in the pressure-vacuum method $(6.42 \%)$ in the yellow pine, and the lowest in beech immersion $(0.30 \%)$. Dişli (2018) reported that the highest $\%$ retention was on $\left(\mathrm{Al}_{2} \mathrm{SO}_{4}\right)_{3}$ as $(9.90 \%)$ and the lowest $\%$ retention was on $\mathrm{Ba}$ as $(1.07 \%)$ in scotch pine wood, and the increase in solution concentration increased the amount of retention. In terms of flexural resistance, the flexural resistance value of plant extracts (extract) increased in both types of wood. The results reflect a positive structure when compared with the literature.

\subsection{Retention Amount (\% Retention)}

The bending strength change is given in Table 3 and Figure 2. Highest bending strength is in evelik plant extract from spruce wood $\left(100.20 \mathrm{~N} / \mathrm{mm}^{2}\right)$, the lowest was observed in çaşır plant extract from mahogany wood $\left(82.22 \mathrm{~N} / \mathrm{mm}^{2}\right)$. 
Table 3. Bending Strength Change of Çakşır (Ferula comunis L.) and Evelik (Rumex patientia L.) Plants $\left(\mathrm{N} / \mathrm{mm}^{2}\right)$.

\begin{tabular}{|c|c|c|c|c|}
\hline $\begin{array}{l}\text { Wood } \\
\text { Type }\end{array}$ & $\begin{array}{c}\text { Concentration } \\
(\%)\end{array}$ & Extract & $\begin{array}{l}\text { Vacuum/Diffusion } \\
\text { Time (min) }\end{array}$ & $\begin{array}{c}\text { Bending Strength } \\
\left(\mathrm{N} / \mathrm{mm}^{2}\right)\end{array}$ \\
\hline \multirow{4}{*}{ Spruce } & \multirow{4}{*}{$\% 1$} & Control sample & \multirow{6}{*}{$45 \mathrm{~min}$} & 83.15 \\
\hline & & Rumex patientia L. & & 100.20 \\
\hline & & Ferula comunis L & & 87.26 \\
\hline & & Control sample & & 70.10 \\
\hline \multirow[t]{2}{*}{ Mahogany } & \multirow{2}{*}{$\% 1$} & Rumex patientia L. & & 88.80 \\
\hline & & Ferula comunis L. & & 82.22 \\
\hline
\end{tabular}

Figure 2. Bending strength change in impregnated and control groups $\left(\mathrm{N} / \mathrm{mm}^{2}\right)$.

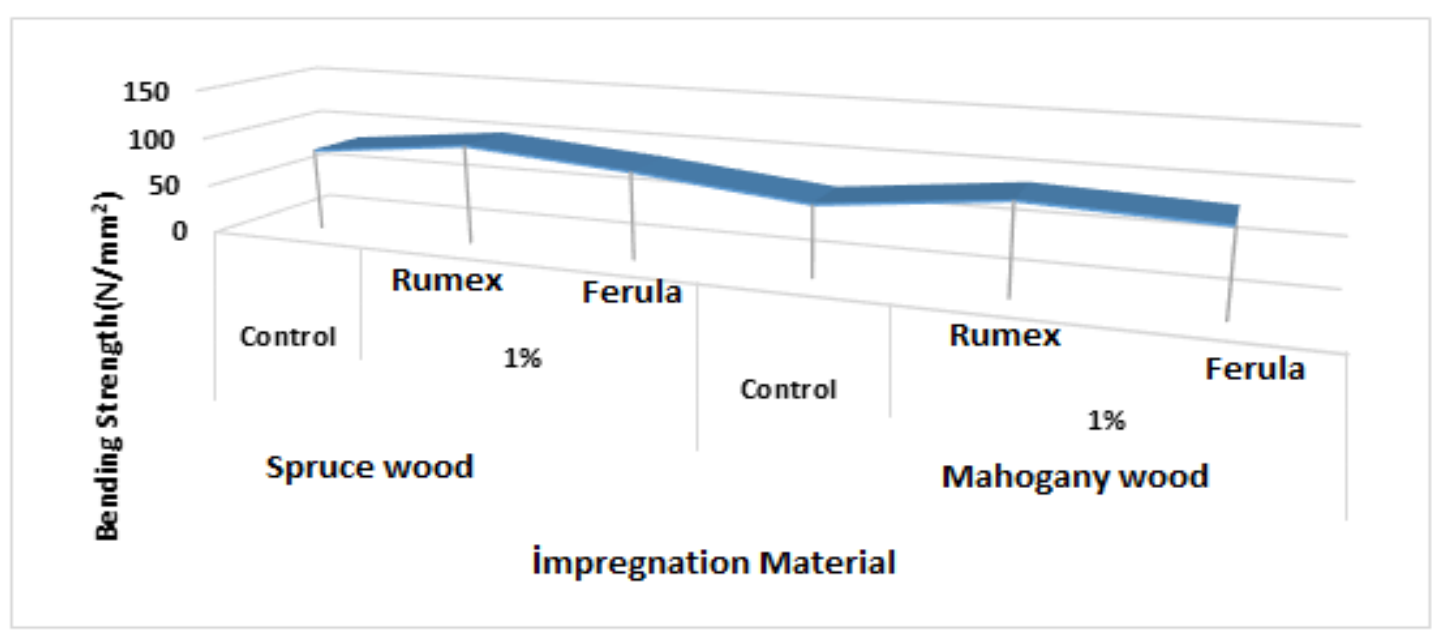

Ertürk (2011) impregnated some types of wood and the flexural resistance according to chemicals were determined; Imersol Aqua $\left(98.177 \mathrm{~N} / \mathrm{mm}^{2}\right)$, Boric acid $\left(95.623 \mathrm{~N} / \mathrm{mm}^{2}\right)$, Tanalith-E $\left(94.708 \mathrm{~N} / \mathrm{mm}^{2}\right)$ and Borax $\left(85.926 \mathrm{~N} / \mathrm{mm}^{2}\right)$. In the F test, which was carried out to determine the flexural resistance of the ash, leafy rowan massive wood materials impregnated with various preservatives; He reported that bending resistance values according to tree species showed statistically significant differences. Çitak (2012) impregnated eastern beech (Fagus orientalis L.) wood with $2.5 \%$ boric acid and borax solution, and determined that the decrease in the flexural resistance was higher in experimental samples impregnated with borax. It was determined that the elastic modulus values of the experimental samples that were not subjected to impregnation were lower than the non-impregnated test samples.

Çakır (2012) chipped the bond pruning residues and subjected them to impregnation with boron compounds (1-4\%) and it was reported that the impregnation process with boron compounds and the increase in the solution concentration in general caused decreases in the flexural resistance and elastic modulus of the test samples.

\section{CONCLUSION}

Healthy life in the human-environment relationship is provided by the wooden equipment used in the indoor and outdoor spaces where it lives. The natural strength of wood in simple use is not long lasting. This causes huge losses in terms of the country's economy and forest resources. Many of the wood preservatives are of chemical origin, which required orientation towards organic / natural preservatives. Suggestions have been made by determining the various technological features of the Evelik plant, which has an important place in terms of healthy life, and also has antioxidant / antibacterial properties, in order to determine the level of adhesion and usage areas in wood. 


\section{Acknowledgments}

This study published in "ICOEST 2020 Proceedings of International Conference on Environmental Science and Technology".

\section{Declaration of Conflicting Interests and Ethics}

The authors declare no conflict of interest. This research study complies with research publishing ethics. The scientific and legal responsibility for manuscripts published in IJSM belongs to the authors.

\section{Authorship Contribution Statement}

Huseyin Peker: Laboratuary work, the methodology and statistical analysis of results, the writing of original draft. Hatice Ulusoy: The collection of plant materials and the other performing technological tests.

\section{Orcid \\ Huseyin Peker (D) https://orcid.org/0000-0002-7771-6993 \\ Hatice Ulusoy (iD https://orcid.org/0000-0003-0960-3388}

\section{REFERENCES}

Alkan, E. (2016). Determination of physical and mechanical properties of scotch pine (Pinus sylvestris L.) wood which impregnated boron compounds and naturel substances (in Turkish) [Master Thesis]. Gumushane University.

ASTM D 1413-76 (1984). Standartd methods of testing preservatives by laboratory soilblock cultures. Annual Book of ASTM Standarts, USA Wood.

Bal, B.C. (2006). Investigation of some physical and mechanical properties of scots pine (Pinus sylvestris L.) wood treated with ammonical copper quat (ACQ) (in Turkish) [Master Thesis]. Kahramanmaras Sutcu Imam University.

Baysal, E. (1994). Çeşitli borlu ve WR bileşiklerin kızılcam odununun bazı fiziksel özelliklerine etkisi (in Turkish) [Master Thesis,], Karadeniz Technical University.

Baytop, T. (1984). Türkiye'de Bitkiler ile Tedavi (in Turkish). İstanbul Üniversitesi Yayınları, No:3255- Eczacillk Fakültesi, No. 40, Istanbul.

Bazyar., B, Parsapajouh, D., \& Khademiesalam, H. (2010). An investigation on some physical properties of oil heat treated poplar wood. 41. IRG Annual Meeting, Biarittz, 10-40509.

Ceylan, A. (1997). Tıbbi Bitkiler II (Uçucu Yă̆ Içerenler) (in Turkish). Field Crops Department, Faculty of Agriculture, Ege University, 188.

Çakır, G. (2012). Determination the effect of vine pruning stalks impregnated with olive black water containing boron were manufactured particleboard on mechanical, physical and decay resistance (in Turkish) [Master Thesis]. Mugla S1tkı Koçman University.

Çetin, S. (2017). Determination of antioxidant and antimicrobial activities of some plants used in medical between adults and people in the Erzurum province (in Turkish) [Master Thesis]. Artvin Coruh University.

Çıtak, O. (2012). Determining some pyhsical and mechanical properties of east beech wood (Fagus orientalis L.) which is heat-treated after impregnated with borax and boric acid (in Turkish) [Master Thesis]. Karabuk University.

Dişli, B. (2018). Effects of technological properties on scoth pine (Pinus sylvestris L.) of some mordant and varnishes (in Turkish) [Master Thesis]. Artvin Coruh University.

Ertürk, N.S. (2011). Technological properties of rowan (Sorbus Aucuparia Lipsky) wood impregnated with various chemical materials (in Turkish) [Master Thesis]. Gazi University.

Njume, C., Afolayan, A.J., \& Ndip, R.N. (2010). An overview of antimicrobial resistanceand the future of medicinal plants in the treatment of helicobacterpylori infections. Afr. J. Pharm. Pharmacol., 3, 685-699. 
Özçifçi, A., \& Batan, F. (2009). Effect of Some Mechanical Properties on Wood Materials Impregnated with Waste Boron Oil. Journal of Polytechnic, 12(4), 287-292.

Özkan, Z.C., \& Akbulut, S. (2014). Ormancılık Uygulamaları Ders Notları (in Turkish). Faculty of Forestry, Karadeniz Technical University, Trabzon s:1-2.

Souza, E.L., Stamford, T.L. M., Lima, E.O., Trajano, V.N., \& Filho, J.M.B. (2005). Antimicrobial effectiveness of spices: an approach for use in food conservation systems. Brazilian Archives of Biologyand Technology, 48, 549-558.

Tomak, E.D. (2011). The effect of oil heat treatment and emulsion techniques on decreasing the leachability of boron in wood (in Turkish) [Doctoral Thesis,]. Karadeniz Technical University.

TS 2470. $\left(1976^{\mathrm{a}}\right)$. Odunda fiziksel ve mekaniksel deneyler için numune alma metodları ve genel özellikler (in Turkish). TSE, Ankara.

TS 2471. $\left(1976^{\mathrm{b}}\right)$. Odunda fiziksel ve mekaniksel deneyler için rutubet miktarı tayini (in Turkish). TSE, Ankara

TS 2474. $\left(1976^{c}\right)$. Odunun statik eğilme dayanımının tayini (in Turkish). TSE, Ankara

Yiğit, N., \& Benli, M. (2005). Ülkemizde yaygın kullanımı olan kekik (Thymusvulgaris) bitkisinin antimikrobiyal aktivitesi (in Turkish). Orlab On-Line Mikrobiyoloji Dergisi, $3(8), 1-8$. 